\title{
RISKS AND PROBLEMS OF FORMING UNITED TERRITORIAL COMMUNITIES IN UKRAINE
}

\author{
L. Ya. Novakovsky ${ }^{1}$, I. O. Novakovska ${ }^{2 *}$, O. O. Bredikhin ${ }^{2}$, \\ M. P. Stetsiuk ${ }^{2}$, L. R. Skrypnyk ${ }^{2}$ \\ ${ }^{1}$ National Academy of Agrarian Sciences of Ukraine, \\ 9, Omelianovycha-Pavlenka Str., Kyiv-10, 01010, Ukraine \\ ${ }^{2}$ National Aviation University, \\ 03058, Kyiv, 1, Kosmonavta Komarova prosp., Ukraine
}

E-mail:novmailll@ukr.net,nov@nau.edu.ua2*

Received May 8, 2019 / Received June 10, 2019 / Accepted July 19, 2019

\begin{abstract}
Aim. To determine the specificities of uniting territorial communities at the national and regional levels during the process of power decentralization, to generalize the experience of its legal and organizational provisions, the practice of reforming local self-government in the EU member states, to estimate the risks of decentralization in Ukraine in general and in rural area in particular, and to establish the directions of its development at the final stage. Methods. Monographic, mathematical-statistical, cartographic, abstract-logical, comparative, analytical analysis. Results. The work conducted during the first stage of decentralization reform (2014-2018), was estimated by the Council of Europe as the most successful reform in progress in Ukraine. As of January 01, 2015, $85.2 \%$ of territorial communities were located in rural areas, where agriculture is the prevailing kind of the population's activity. Thus, power decentralization and reforming local self-governance refers to rural population, first and foremost. However, the study has confirmed that the implementation of reforming remedies has been restrained, as the main provisions of decentralization have not been enshrined in the Constitution, there are no definite plans on developing united communities, it is impossible to overcome the removal of local councils from managing land resources beyond the boundaries of settlements, the reform is being blocked by regional and district state authorities. Conclusions. Current system of rural population settlements, characterized by a considerable number of small villages, the specificity of territorial organization of power ( $40 \%$ of local councils have less than 1,000 residents) and village and town budgets, subsidized for almost $50 \%$, are prerequisites of uniting communities as the only way of forming sustainable local self-governance. The centralization of authorities by the executive branch regarding governance over territories, low spreading of local self-governance and absence of land resources in communal ownership, financial limitedness of councils prove that without principal changes in the current position, most territorial communities will still remain unsustainable in legal, organizational and financial aspects. The experience of implementing decentralization tasks in regions demonstrates that the level of organizational and explanatory work and control over reforming should be enhanced considerably. The issues of regulating the division of mountainous territories and setting higher bonuses and benefits, improving budget limits of the communities via taxation system, enhancing the role of cities of regional significance as centers of united territorial communities should be settled at the legislative level. At this stage, the risks of implementing decentralization in Ukraine are as follows: the impossibility of completing the plan of implementing the remedies of its second stage without amending the Constitution, unclear mechanisms of implementing the remedies of reforming local self-governance, because regional councils are too politicized, while state regional administrations perform functions, non-relevant for them, and resist; the absence of promising plans of social and economic development of territorial communities restrains the process of substantiating their capability and the terms of implementing decentralization; ignoring the requirements related to needless district councils in cases called «one district - one community»; absence of actions in terms of determining the boundaries of communities or changing the boundaries of districts; absence of work in reflecting the process of land division by ownership forms in the State Cadaster; untimely solving the problems of human resources for executive bodies of territorial communities and delegating relevant authorities to them.
\end{abstract}

Keywords: territorial communities, decentralization, communal ownership of land, local self-governance, land cadaster documentation, determining the boundaries of communities.

DOI: https://doi.org/10.15407/agrisp6.02.066

(C) L.Ya. NOVAKOVSKY, I.O. NOVAKOVSKA, O.O. BREDIKHIN, M.P. STETSIUK, L.P. SKRYPNYK, 2019 


\section{INTRODUCTION}

Despite the implemented measures of reforming local self-governance, the state power in Ukraine is still too centralized. Local self-government bodies (village, town, city councils), being government authorities, the closest to people, are incapable of solving all the local issues in accordance to the provisions of the European Charter of Local Self-Government [1]. The delegation of relevant authorities to local self-government along with uniting territorial communities as well as providing them with land and financial resources and introducing widespread local self-government is the essence of decentralization, which started in 2014.

Ukraine is the largest country in Europe. The total area is 60.4 million ha and the population amounts to 45.4 million people. Agricultural land covers 41.5 million ha, arable land -32.5 million ha, and other areas, covered with forest -10.6 million ha. The agricultural reclamation of territory is $68.8 \%$ (the highest in Europe), ploughness - $53.9 \%$ (the highest in Europe), and woodiness $-17.6 \%$, i.e. the lowest among European countries [2]. Almost 2/3 of the total area of agricultural land in the country are covered by chernozem soils, considered to be some of the most fertile soils, and its area (27.5 million ha) is ranked the fourth in the world (after Russia, the USA, and China) [3]. Land resource potential of the country and other natural factors promote the development of agricultural production - one of the main sectors of Ukrainian economy, which meets domestic requirements for food and generates the export of agricultural products.

Pursuant to administrative-territorial structure as of January 01, 2015, Ukraine consisted of the Autonomous Republic of Crimea, 24 regions, cities with special status - Kyiv and Sevastopol, 490 districts, 460 cities, 885 towns, 28,388 villages. The mentioned settlements were united in 12,063 councils, including 490 district councils, 458 - city councils, 783 - town councils, 10,279 - village councils [4]. Out of the total number of councils (12 thousand), over 6 thousand have fewer than 3 thousand residents, including 4.8 thousand which have fewer than 1 thousand residents, and 1,129 councils - fewer than 500 residents. In most of the latter, the executive bodies of the village councils have not been formed, there are no budget institutions and communal enterprises. The 5.4 thousand budgets of self-governance bodies were subsidized for over $70 \%$, 483 village councils were kept at the expense of state budget [5]. Therefore, reforming local self-government has become more relevant.
The decentralization in Ukraine was started in 2014 with the adoption of the Concept of reforming local self-government and territorial organization of power (January 01, 2014) and the Law of Ukraine «On Cooperation of Territorial Communities» (June 17, 2014). The conceptual documents stipulated the introduction of amendments to the Constitution of Ukraine. These changes were related to the formation of executive bodies of regional and district councils, reorganization of state local administrations as executive authorities into the bodies with supervising and controlling functions, improvement of administrative-territorial structure and determination of territorial community as its basic unit (at present, these units are villages, towns, cities). As the amendments to the Constitution have not been supported by the Parliament of Ukraine, the reform is done within current constitutional norms based on new adopted legislative acts: on amending the Budget and Tax Codes; on voluntary uniting of territorial communities; on fundamentals of state regional policy; on extending the authorities and optimization of the provision of administrative services by self-government bodies. A relevant role in reforming local self-government was played by the Methodology of forming sustainable territorial communities, approved by the Government of Ukraine (April 08, 2015).

The decentralization process in Ukraine includes several interrelated reforms: territorial organization of power, local self-government, regional policy and interbudget relations. Simultaneous implementation of a number of the abovementioned decentralization reforms in conditions, when the land reform is in progress in the country, is one of the specificities and differences of the Ukrainian reform. It should be noted that this implementation was negatively impacted by the occupation of the Autonomous Republic of Crimea and some territory of the Donetsk and Luhansk regions. The decentralization reform was practically suspended on these territories. Temporarily occupied territories cover the area of 4.5 million ha [6]. Thus, the territory with the ongoing decentralization reform was reduced by $13.4 \%$, the number of territorial communities was decreased by 1,111 , and the number of districts - by $25 \%$.

Among the territorial communities, existing as of January $01,2015,85.2 \%$ were the communities, uniting village and town councils, i.e. the ones, located in rural areas. The area of agricultural fields in these communities was 41.13 million ha or $99 \%$ of all the area of the mentioned fields in the country. In this ter- 
ritory, agriculture is the prevailing kind of activity. Therefore, power decentralization and reforming local self-government is related to rural population first and foremost, the location and functioning of agricultural enterprises and rural households [2].

The issue of decentralization has been a point of dispute in most European countries within the recent decade [7].

The European Union continues the program of supporting decentralization in Ukraine, «U-LEAD with Europe», which is financed by the EU and its member-states: Denmark, Estonia, Germany, Poland, and Sweden. International projects for reforms in Ukraine are also implemented by other expert and public organizations. The generalization of the experience of legal and organizational provisions and implementation is of considerable interest both for Ukraine and for other countries of Europe. This experience is interesting for Belarus, Moldova, Slovakia, Czech Republic and Belgium [8].

The analysis of long-term experience of reforming local self-government in Slovakia demonstrates that the need for progress in the field of state local self-governance and local development is among the stimuli for positive consequences: democratization, decentralization and modernization [9]. 25 years of reforming local self-governance have demonstrated that the reform of state administration in Slovak Republic is not completed yet, as the own income of the municipalities comprises only $11 \%$ of the total income [10].

During recent 45 years the territorial issue has had the central position in Belgium, which witnessed considerable transformations in the field of state decentralization [11].

Special relevance is attributed to the study of the directions and ways of implementing the second stage of decentralization, which was started in 2019 at the initiative of the Government of Ukraine, in particular, in terms of forming a new territorial basis of the country at the level of communities and districts.

In recent 10-20 years, the process of uniting communities concerned over a dozen of European countries. The reforms of territorial organization of power have had considerable differences. For instance, there is no division of local self-government bodies into representational and executive ones at the lowest level in Great Britain. In Scandinavian countries, reforming was based on the principles of economic independence of local communities, partnership and cooperation. In
Southern Europe (France, Spain), the main prerequisite of decentralization was completely voluntary participation in the communities. This fact conditioned the incompleteness of reforms in some countries, refusal from the participation or establishing the network of intercommunale [12].

There are different deadlines for implementing decentralization reforms. For instance, in Norway the completion of the decentralization reform is scheduled for January 01, 2020. The number of regions will be reduced from 19 to 10 , and municipalities - from 428 to 356 , the main principle of reforming is voluntary participation, but it may be omitted for especially small municipalities. The decentralization process in this country will last for two and a half years. Denmark conducted the reform in 1960-2007, uniting 270 municipalities into 98, and from 2003 to 2015 Sweden reformed 25 regions into 10 [13].

The specificity of the Polish decentralization reform was its being enshrined in the Constitution. In Poland, the decentralization of the country occurred due to administrative, political and economic reasons [14]. There is a declared principle which states that «the territorial structure of the country ensures the decentralization of public authority, and self-governed community performs public functions on its behalf and at its responsibility» [15]. The preparatory period to implementing decentralization lasted ten years, and the reform was conducted from 1989 till 2000, i.e. 11 years [16]. The stage-by-stage approach, designed for reforming, envisaged the holistic vision of its implementation even at the first stage. Specific positions and criteria were specified later. Poland is believed to be one of the most decentralized countries of Europe, as the local self-government controls a third of all the state expenses [17].

The complexity of adapting international experience in terms of introducing decentralization is conditioned by unique conditions of each country. According to the Constitution, the territorial structure of Ukraine is based on the fundamentals of unity and integrity of its state territory, balanced social-economic development of the regions. Historic, economic, ecologic, geographical and demographic specificities were taken into consideration along with ethnic and cultural traditions [18]. The scientific substantiation of stage-by-stage approach to decentralization should be based on mutual impact and predicament of all the abovementioned factors, specificities and traditions.

The problems of decentralization were studied by many domestic and foreign scientists. The most known 
articles are scientific works by V. Bordenyuk, O. Boryslavska, Ch. Tiebout, Z. Varnaliy and N. Nyzhnyk. The analysis of local self-governance in foreign countries demonstrates the use of several models. As it was pointed out by $\mathrm{V}$. Bordenyuk, the efficiency of any administration system is determined by the ratio of functions and authorities of state power bodies, their distribution by functional and branch-wise principles. Depending on the relations with state power bodies and the volume of authorities, there are models of local autonomy and decentralization. Spain and Italy serve as an example of autonomy, and France - that of decentralization. During reorganization of local self-governance in France, the number of regions in the country should be reduced from 22 to 13 . The reform came into force on January 31, 2016 [19, 20].

O. Boryslavska states that the essence of decentralization is the division of tasks and functions, according to which most of them are delegated from the level of central authorities to the lower level and become the task and authority of the latter. [21] One may not ignore the conclusion of the American researcher, I. Tiebout, who said that decentralization of production met the needs of citizens better than centralized planning [22].

However, decentralization is not always related to the delegation of public services to local self-governance authorities. The main form of decentralization in many developed countries is the Alternative Services Delivery (ASD). Non-state and private sectors are known for their provision of services with smaller expenses.

According to the plan of implementing the measures for the second stage of decentralization, its essence lies in solving key issues regarding the formation of new territorial basis of the country, delegation of the authorities to the self-government bodies and creation of the proper resource basis for citizens to exercise their authorities. Due to the fact that the processes of power decentralization have been under way in our country for five years, complex monographic studies of the experience obtained are still limited. The monographs and other publications of A. Tkachuk and Yu. Hanushchak contain the analysis of the course of reforms and the ways of their completion [23, 24].

The aim of the article is to determine the specificities of uniting territorial communities at the national and regional levels during the process of power decentralization, to generalize the experience of its legal and organizational provisions, the practice of reforming local self-government in the EU member states, to estimate the risks of decentralization in Ukraine in general and in rural area in particular, and to establish the directions of its development at the final stage.

\section{MATERIALS AND METHODS}

In order to solve the aims of the study, the monographic method of analyzing specialized literature, legislative and program documents, regulating the formation of united territorial communities, including rural areas, was used along with abstract-logical and comparative methods.

While processing statistical materials, including the data of the State service of Ukraine on geodesy, cartography and cadaster, the authors used mathematical, graphic and mapping methods.

On-line media, systematically publishing information on this topic, include the national portal «Decentralization». The Monitoring of power decentralization process and reforming local self-government in Ukraine is published monthly regarding each region [6].

\section{RESULTS AND DISCUSSION}

As of May 10, 2019, 4,187 communities were united into 899 united territorial communities, out of which 65 communities joined the newly created ones, and 63 joined 26 cities of regional significance*. In 2018 the communities of the cities of regional significance were recognized to be capable by law. The area of united territorial communities is 217.5 thousand sq.m. (38.9 $\%$ of the total area of the country, without temporarily occupied territories). The number of residents in the united territorial communities is 9.5 million people (27.0\% of the total number of Ukrainian population, without temporarily occupied territories). The number of united territorial communities in terms of regions is presented in Fig. 1, and the dynamics of forming communities in Ukraine in general in 2015-2019 is characterized by the data, presented in the chart (Fig. 2) (as of May 10, 2019).

As of May 10, 2019, in Ukraine 6,774 territorial communities $(61.8 \%$ of the total number of councils at the basic level) remain non-united (without temporarily occupied territories) (Fig. 3).

The number of districts, where no united territorial community has been formed, is 94 , and the promising plans of forming capable territorial communities, approved by the Government, cover $81.9 \%$ of the territory of the country. Odesa $(34.3 \%)$, Vinnytsia $(41.3 \%)$, Poltava $(48.5 \%)$ regions have the smallest 


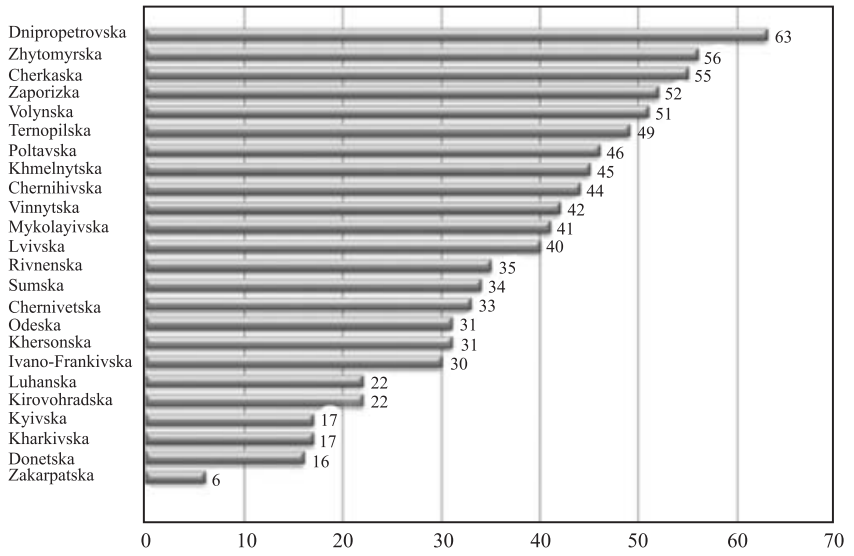

Fig. 1. The number of united territorial communities in terms of regions. Source: elaborated by the authors. The digital data about uniting the communities, their characteristics, dynamics of formation, consequences of implementing the first stage of decentralization are presented according to the source [6] and authors' elaborations

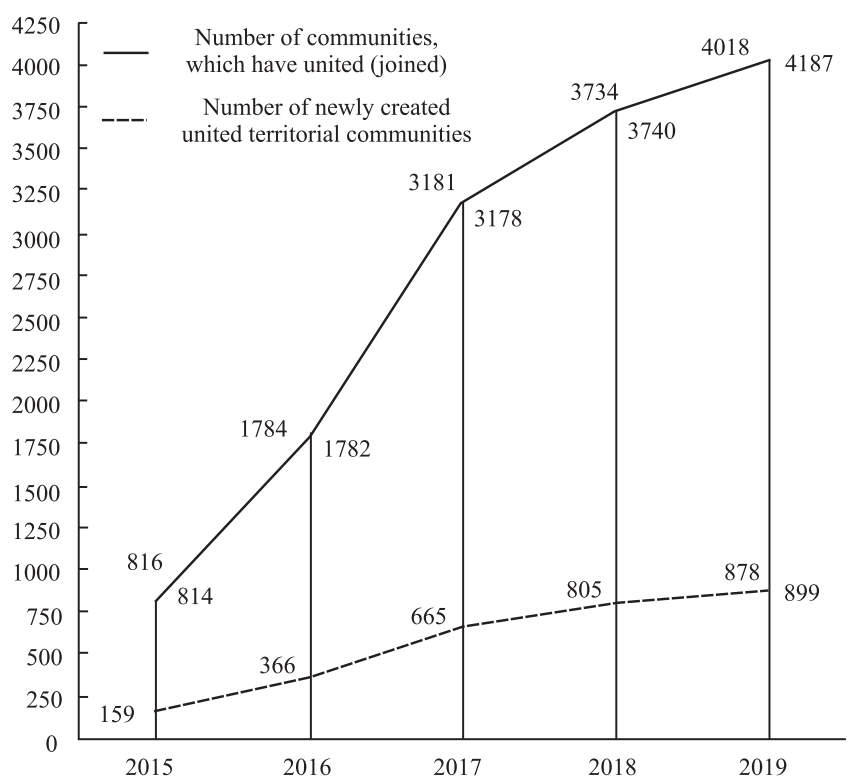

Fig. 2. The formation of united territorial communities. Source: elaborated by the authors

indices of covering their territory by the mentioned plans. The perspective plan has not been approved for Zakarpatska region yet.

While estimating the general consequences of implementing the first stage of decentralization, it should be noted that comparing against 2015, the number of united communities increased up to 899 or 5.7 times, their territorial resources are 21.8 million ha or $38.9 \%$ of Ukraine's territory, and the number of the population of united communities is 9.5 million persons, i.e. it increased 6.8 times in comparison to 2015 .
The comparison of decentralization dynamics in Ukraine against other European countries, whose experience was under our investigation, demonstrates that positive evaluation of Ukraine's achievements by the European Union in this respect is fair. However, attention should be paid to extremely low results of uniting territorial communities in Zakarpatska, Kharkivska, and Kyivska regions in four years. We analyzed the decentralization process in each of the mentioned regions, the main parameters of forming united communities in which are presented in the Table.

Zakarpatska region was established on January 22, 1946, it is located in far south-west of Ukraine and borders four countries - Poland, Slovakia, Hungary and Romania.

Almost $2 / 3$ of the territory of the region are covered by the Carpathian mountains, and the rest - by the Tysa lowland. 192 settlements $(20 \%$ of the total area) have the status of mountainous settlements. The population of the region is presented by 30 nationalities, the major ones being Ukrainians (80.5\%), Hungarians (12.1\%), Romanians (2.8\%), Russians $(2.8 \%)$. Hungarian national minority lives densely in the territory of Berehivskyi, Uzhhorodskyi, Vynohradivskyi and Mukachivskyi districts (Transcarpathia lowland), and Romanian national minority - in ten settlements of Tiachivskyi and Rakhivskyi districts (Fig. 4).

337 territorial communities were in the region prior to uniting. Three out of six united territorial communities - Irshavska, Perechynska, and Tiachivska are town communities. All six new territorial communities were formed in piedmont districts. There was no uniting of communities in mountainous districts. There is a similar situation in the districts of Tysa lowland, where the Hungarian national minority lives.

The situation with reforming local self-government in the region is conditioned by two groups of factors. The first one includes blocking the decentralization process by the state regional administration and some district administrations, as well as considerable drawbacks of the organizational work in reforming (ignoring the requirements of perspective plan of forming capable communities and submitting the materials for the consideration of the regional council and the Central Election Commission of Ukraine, absence of proper explanatory work, low level of controlling the activity of village and town councils on the issues of implementing the reform). 


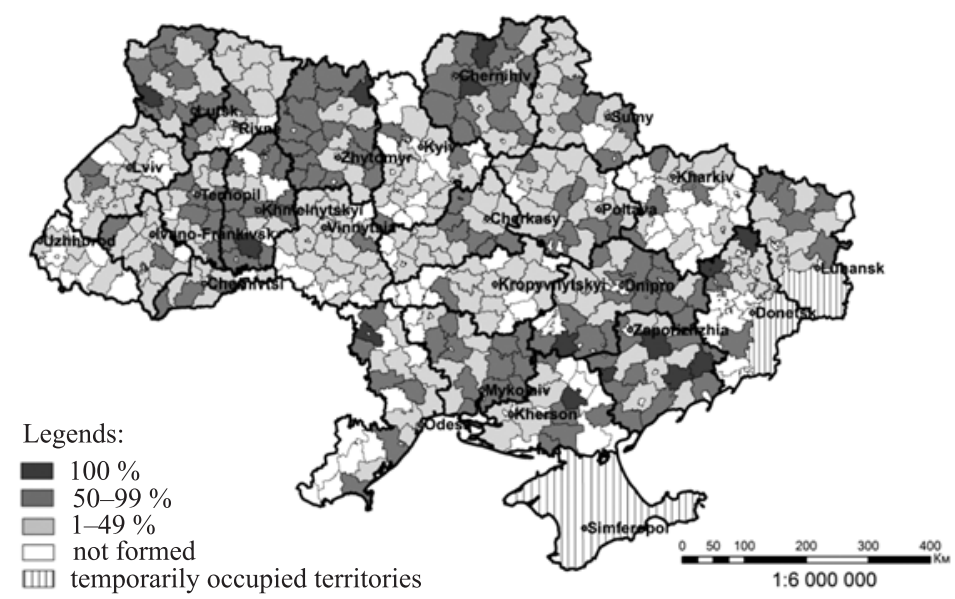

Fig. 3. The uniting of territorial communities within districts in the territory of Ukraine. Source: elaborated by the authors

The second group of factors, restraining the processes of reforming local self-government and territorial organization of power, are as follows:

a) absence of the required number of working places to ensure the employment of residents, living in the mountainous districts and absence of elaborated programs of developing the mentioned districts in the structure of decentralization materials (creating industrial parks, development of tourism, wood-processing industry, eco-business, preserving natural heritage, creating ecologic objects, etc.). The results, obtained by the scientists of the Transcarpathian regional center of socio-economic and humanitarian studies, according to such criteria as social infrastructure, resources, business activity, demonstrated that $55 \%$ of the communities in the region have very low economic potential UAH 350 of income per one individual in 2015 (mostly mountainous districts). At the same time, this index in the most economically developed communities (Uzhhorod group) is UAH 5,000 of income per person [25]. The issue of creating capable territorial communities in mountainous districts cannot be solved without elaborating the programs of their development, settling the issues of proficit and deficit, creating relevant industrial structures. The abovementioned conditioned the prolongation of the preparatory period and implementation of decentralization tasks:

b) legislative imperfection of the division of mountainous territories and the need to isolate them in the composition of high-mountain areas while setting higher subsidies and bonuses for them;

c) budgetary limitation of communities due to the payment of taxes by the enterprises and industrial capacities at the place of registration of their management body (Kyiv, Odesa, Kharkiv, Dnipro, Lviv) and not at the place of locating industrial capacities within the jurisdiction of specific communities;

d) the specificities of considering the system of dense settlement of national minorities while solving the issue of uniting communities.

In Kharkivska region, two first years of reforming (2014, 2015) were spent organizing and preparing due to the absence of accurate information, special misrepresentation of the reforming fundamentals by some local officials and great resistance on their part. In 2016 alone, 4 out of 57 united communities, approved by the perspective plan, were formed. That is when the decision was made - not to disrupt the principle of voluntary involvement, but to focus on solving the following issues:

The main parameters of forming united territorial communities (UTC) in specific regions

\begin{tabular}{l|c|c|c|c|c|c|c}
\hline \multirow{2}{*}{ Region } & \multirow{2}{*}{$\begin{array}{c}\text { Total number } \\
\text { of UTC }\end{array}$} & \multicolumn{4}{c|}{ Including, in terms of years } & \multicolumn{2}{c}{$\begin{array}{c}\text { Territorial communities, } \\
\text { which have united }\end{array}$} \\
\cline { 3 - 8 } & & 2015 & 2016 & 2017 & 2018 & number & $\%$ \\
\hline Zakarpatska & 6 & 2 & 1 & 3 & - & 20 & 5.9 \\
Kharkivska & 17 & - & 4 & 8 & 5 & 79 & 17.2 \\
Kyivska & 17 & 1 & 1 & 7 & 8 & 108 & 16.4 \\
\hline
\end{tabular}




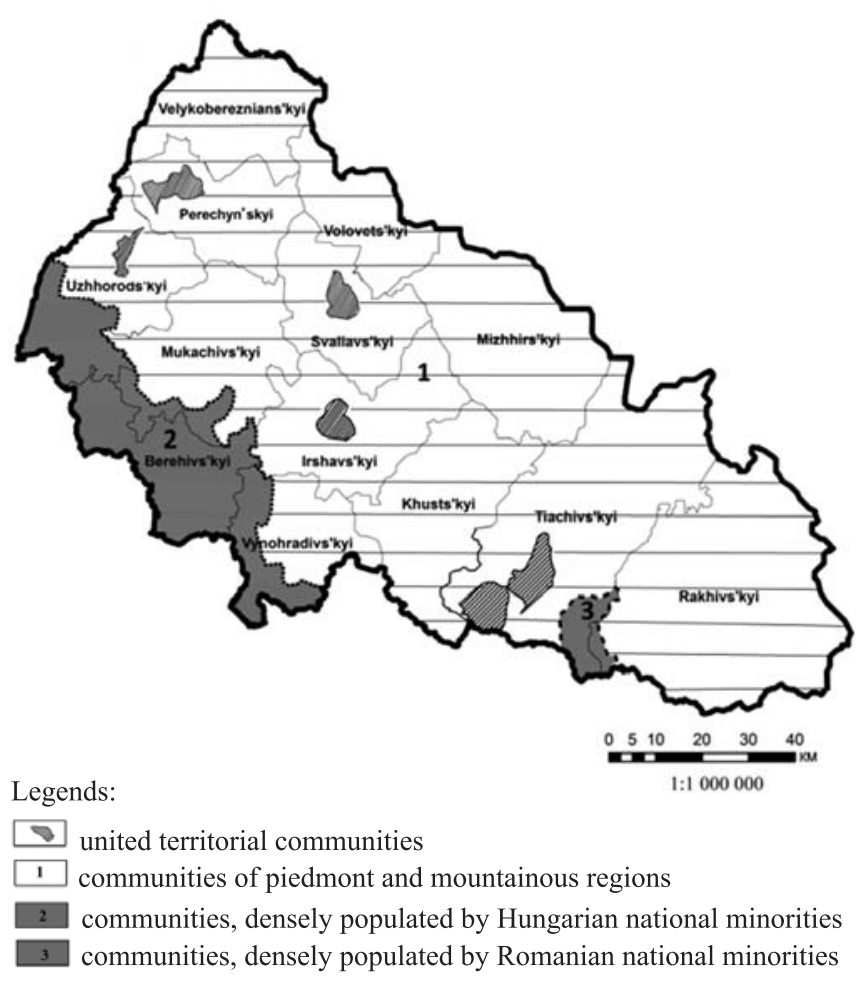

Fig. 4. The scheme of locations of territorial communities in Transcarpathia region

- organizing information distribution about the aim, tasks, terms of decentralization;

- believing the priority to be the creation of capable communities, which would rise to the development in the nearest future;

- developing a clear perspective program: action plan, source of income, possible expenses, budget accumulation, allocation of finances, directions of investing;

- instead of impacting local self-government bodies, attracting international partners and donors, in particular, the Consulate General of Poland in Kharkiv, and establishing its own center to teach personnel, to elaborate the required documentation, to organize assistance for local self-government bodies.

At the end of 2018, the implementation of the mentioned tasks resulted in creating 17 large capable territorial communities in Kharkivska region, which cover $18.4 \%$ of the regional territory. This path was also chosen in Kyivska region, where 17 newly created communities included three cities of regional significance that had joined some communities, giving rise to further similar uniting of other territorial communities.

Taking into consideration this study, the following conclusions may be made about the risks of decentralization:
1) the Parliament does not have enough votes to amend the Constitution of Ukraine about the implementation of decentralization concept. It is impossible to complete the plan of implementing the remedies of its second stage without the introduction of constitutional changes. Therefore, the three-year-long period, allocated to complete reforms (2019-2021), is not substantiated sufficiently;

2) regional councils are too politicized, and the state regional administrations perform the functions, uncharacteristic for them in terms of reforming local self-government, and present their resistance. Here legislative norms are ignored, but there are no defined mechanisms of implementing remedies;

3) due to absent perspective plans of social-economic development of united territorial communities, the process of substantiating the capability of united communities and the terms of decentralization implementation is restrained;

4) the requirements regarding excessive district councils in cases «one district - one community» are ignored.

5) the boundaries of the communities are neither being determined nor changed, there is no work in terms of reflecting the process of dividing the land by ownership forms in the State Land Cadaster [26];

6) the problems of staffing the executive bodies of territorial communities and delegating relevant authorities to them are not solved on time.

\section{CONCLUSIONS}

Among the consequences of implementing the tasks of the first decentralization stage in Ukraine, there is an evident considerable increase in the number of united territorial communities with the territorial resources of over $40 \%$ of the total area of state land, $85.2 \%$ of which are communities, uniting village councils, and the number of residents with the consideration of the cities of regional significance, is $69.9 \%$ of the total population.

The main drawbacks of the first decentralization stage should be defined as follows: the main provisions of decentralization are not enshrined in the Constitution, the preparatory period is extremely limited, there are no programs of perspective development of the communities, the reform is blocked by some state administrations and district councils.

The completion of decentralization process should be directed at adopting legislative acts on transferring the land beyond settlements into communal ownership, 
amending the Land code of Ukraine, laws on land structure and the State Land Cadaster in terms of determining the boundaries of the communities and composing the schemes of land structure, expanding the composition of land cadaster documentation. The authorities of united territorial communities in terms of regulating land relations at the local level should be defined in legislation. The completion of forming communal ownership on land will both demonstrate the success of decentralization and allow implementing the tasks of land reform.

\section{Ризики та проблеми формування об'сднаних територіальних громад в Україні}

Л. Я. Новаковський ${ }^{1}$, І. О. Новаковська ${ }^{2 *}$, О. О. Бредіхін ${ }^{2}$, М. П. Стецюк ${ }^{2}$, Л. Р. Скрипник ${ }^{2}$

${ }^{1}$ Національна академія аграрних наук України, 9, Вул. Омел'яновича-Павленка, Київ, 01010, Україна

${ }^{2}$ Національний авіаційний університет, Проспект Космонавта Комарова, 1, Київ, 03058

e-mail: novmaill1@ukr.net 2*,nov@nau.edu.ua ${ }^{2^{*}}$

Мета. Визначити особливості об'єднання територіальних громад на загальнодержавному та регіональному рівнях у процесі децентралізації влади, узагальнити досвід iіi правового й організаційного забезпечення, практику реформування місцевого самоврядування в країнах Європейського Союзу, оцінити ризики децентралізації в Україні і зокрема в сільській місцевості та сформувати напрями їі розвитку на завершальному етапі. Методи. Монографічний, математико-статистичний, картографічний, абстрактно-логічний, порівняльний, аналітичний аналіз. Результати. Обсяг робіт, виконаний протягом першого етапу реформи децентралізації (20142018 рр.), дав можливість Раді Європи оцінити цю реформу як найуспішнішу з усіх реформ, що здійснюються в Україні. Серед територіальних громад 85,2 \% (на 1.01.2015 р.) складають громади, що розташовані у сільській місцевості, де сільськогосподарська діяльність населення $є$ переважаючим видом діяльності. Отже, децентралізація влади та реформування місцевого самоврядування стосується передусім сільського населення. Однак дослідженням підтверджено, що реалізація заходів із реформування стримувалася через конституційну незакріпленість основних положень децентралізації, відсутність чітких планів розвитку об'єднаних громад, неподоланність відсторонення місцевих рад від управління земельними ресурсами за межами населених пунктів, блокування реформи обласними та районними органами виконавчої влади. Висновки. Існуюча система розселення сільського населення, що характеризується значною кількістю дрібних сіл, особливістю територіальної організації влади (40 \% місцевих рад мають населення менше 1 тис. осіб) та дотаційністю майже $50 \%$ сільських і селищних бюджетів, зумовлюють укрупнення громад як єдиний захід формування спроможного місцевого самоврядування. Зосередженість повноважень щодо управління територіями в органах виконавчої влади, відсутність повсюдності місцевого самоврядування та земельних ресурсів у комунальній власності, фінансова обмеженість рад підтверджують, що без кардинальної зміни існуючого положення більшість територіальних громад і надалі залишатимуться неспроможними у правовому, організаційному та фінансовому відношеннях. Досвід реалізації завдань децентралізації в регіонах свідчить, що рівень організаційнороз'яснювальної роботи та контролю за реформуванням мають бути істотно підвищені. На законодавчому рівні слід вирішити питання впорядкування поділу гірських територій із встановленням для високогірних районів більш високих розмірів надбавок і пільг, удосконалення бюджетної обмеженості громад через зміну системи оподаткування, підвищити роль міст обласного значення як центрів об'єднаних територіальних громад. Ризиками здійснення децентралізації на цьому етапі в Україні $€:$ неможливість завершення плану реалізації заходів iii другого етапу без внесення змін до Конституції, невизначеність механізмів реалізації заходів реформування місцевого самоврядування, за умов, коли обласні ради $є$ занадто політизованими, а обласні державні адміністрації виконують невластиві для них функції i чинять опір; відсутність перспективних планів соціальноекономічного розвитку територіальних громад стримує процес обгрунтування їхньої спроможності та строки реалізації децентралізації; ігнорування вимог щодо зайвості районних рад у випадках «один район - одна громада»; відсутність упровадження встановлення меж громад, змін меж районів, робіт щодо відображення у Державному кадастрі процесу розмежування земель за формами власності; несвоєчасність вирішення проблем кадрового забезпечення виконавчих органів територіальних громаді передачі їм відповідних повноважень.

Ключові слова: територіальні громади, децентралізація, комунальна власність на землю, місцеве самоврядування, земельно-кадастрова документація, встановлення меж громад.

\section{Риски и проблемы формирования объединенных территориальных общин в Украине}

Л. Я. Новаковский ${ }^{1}$, И. А. Новаковская ${ }^{2 *}$, А. А. Бредихин ${ }^{2}$, М. П. Стецюк ${ }^{2}$, Л. Р. Скрипник ${ }^{2}$

${ }^{1}$ Национальная академия аграрных наук Украины, 9, Ул. Омельяновича-Павленко, Киев, 01010, Украина

${ }^{2}$ Национальный авиационный университет, Украина проспект Космонавта Комарова, 1, Киев, 03058 e-mail: novmaill1@ukr.net ${ }^{2^{*}}$,nov@nau.edu.ua ${ }^{2^{*}}$

Цель. Определить особенности объединения территориальных общин на обще государственном и региональ- 


\section{NOVAKOVSKY et al.}

ном уровнях в процессе децентрализации власти, обобщить опыт ее правового и организационного обеспечения, практику реформирования местного самоуправления в странах Европейского Союза, оценить риски децентрализации в Украине и, в частности в сельской местности, и сформировать направления ее развития на завершающем этапе. Методы. Монографический, математико-статистический, картографический, абстрактно-логический, сравнительный, аналитический анализы. Результаты. Объем работ, выполненный в течение первого этапа реформы децентрализации (20142018 гг.), позволил Совету Европы оценить эту реформу как самую успешную из всех реформ, осуществляемых в Украине. Среди территориальных общин 85,2 \% (на 1.01 .2015 г.) составляют общины, расположенные в сельской местности, где сельскохозяйственная деятельность населения является преобладающим видом деятельности. Итак, децентрализация власти и реформирование местного самоуправления касается прежде всего сельского населения. Однако исследованием подтверждено, что реализация мероприятий по реформированию сдерживалась из-за отсутствия конституционно утвержденных основных положений децентрализации, четких планов развития объединенных общин, отстранения местных советов от управления земельными ресурсами за пределами населенных пунктов, блокирования реформы областными и районными органами исполнительной власти. Выводы. Существующая система расселения сельского населения характеризуется наличием значительного количества мелких сел, особенностью территориальной организации власти (40\% местных советов имеют население менее 1 тыс. человек) дотационностью почти 50 \% сельских и поселковых бюджетов, что обусловливает укрупнение общин как единственную меру формирования способного местного самоуправления. Сосредоточенность полномочий по управлению территориями в органах исполнительной власти, вездесущность местного самоуправления и коммунальной собственности земельных ресурсов, финансовая ограниченность советов подтверждают, что без кардинального изменения существующего положения большинство территориальных общин и в дальнейшем будут оставаться недееспособными в правовом, организационном и финансовом отношениях. Опыт реализации задач децентрализации в регионах показывает, что уровень организационно-разъяснительной работы и контроля за реформированием должны быть существенно повышены. На законодательном уровне следует решить вопросы упорядочения разделения горных территорий с установлением для высокогорных районов более высоких размеров надбавок и льгот, усовершенствование бюджетной сферы общин через изменение системы налогообложения, повышение роли городов областного значения как центров объединенных территориальных общин.
Рисками осуществления децентрализации на этом этапе в Украине являются: невозможность завершения плана реализации мероприятий, его второго этапа, без внесения изменений в Конституцию, неопределенность механизмов реализации мероприятий по реформированию местного самоуправления в условиях, когда областные советы слишком политизированны, а областные государственные администрации выполняют несвойственные для них функции и оказывают сопротивление; отсутствие перспективных планов социальноэкономического развития территориальных общин сдерживает процесс обоснования способности и сроков реализации децентрализации; игнорирование требований районных советов в случаях «один район - одна община»; отсутствие границ общин, изменений границ районов, работ по отражению в Государственном кадастре процесса разграничения земель по формам собственности; несвоевременность решения проблем кадрового обеспечения исполнительных органов территориальных общин и передачи им соответствующих полномочий.

Ключевые слова: территориальные общины, децентрализация, коммунальная собственность на землю, местное самоуправление, земельно-кадастровая документация, установления границ общин.

\section{REFERENCES}

1. The European Charter of Local Self-Government (eng/ rus), Strasbourg, 15 October 1985 (Charter ratified by Law No 452/97-VR of 15.07.97) (available online). http://zakon2.rada.gov.ua/laws/show/994_036.

2. Novakovska I. Urban land management: monograph, Kyiv: Ahrarna nauka. 2016:304 p.

3. Baliuk $S$. Soil resources of Ukraine: condition and measures of its improvement. Visnyk ahrarnoi nauky. 2010; (6):5-10.

4. Monitoring of soil relations in Ukraine: 2016-2017:168 p. Land Transparency. http://land.gov.ua/wp-ontent/uploads/ 2018/10/monitoring.pdf.

5. The Concept of Reforming Local Self-Governance and Territorial Organization of Power in Ukraine (2014) (available online). https://zakon.rada.gov.ua/laws/show/ 333-2014.

6. National Project «Decentralization» (available online). https://decentralization.gov.ua/mainmonitoring.

7. Mazzoleni M. The drafting of the new French regions: The party politics of regional reform. French politics. 2015;13(3):241-65. doi: 10.1057/fp.2015.12.

8. Council of Europe: Decentralization - the Most Successful Reform in Ukraine (available online). https:// today.ua/rada-yevropi-detsentralizatsiya-najuspishnishareforma-v-ukrayini/.

9. Silva CN, Bucek J. Local Government and Urban Governance in Europe introduction. Local Government 


\section{RISKS AND PROBLEMS OF FORMING UNITED TERRITORIAL COMMUNITIES IN UKRAINE}

and Urban Governance in Europe. Book Series: Urban book Series. Springer, Cham. 2017:1-5. doi: 10.1007/ 978-3-319-43979-2_1.

10. Parcunova V, Hudakova J, Beresecka J. Changes in the local self-government in the conditions of Slovak Republic per 25 years. Geographical information. 2018; 22:223-31. doi: 10.17846/G1.2018. 22.2.223-231.

11. Beland D, Lecours A. Federalism, policy change, and social security in Belgium: Explaining the decentralization of family allowances in the Sixth state Reform. J. Eur. Soc. Policy. 2018;28(1):55-69. doi: 10. $1177 / 0958928717700563$.

12. Odarchenko Yu. Decentralization: Experience of European Countries (available online). https://ukr.lb.ua/blog/ yuriy_odarchenko/399704_detsentralizatsiya_dosvid. html.

13. International Development of Decentralization (available online). http://pravo.org.ua/ua/news/20873426-yak-visvitlyuvati-detsentralizatsiyu

14. Carcztecki S. Decentralized, yet Desperate: Regional Policy and Regions in Poland. Osteuropa. 2011;61(56):165 p.

15. Constitution of the Republic of Poland from 2 April 1997 (available online). https://www.sejm.gov.pl/prawo/konst/ angielski/kon1.htm.

16. Regulskiy E. About self-government in Poland. 2013. URL:http://www.novpol.ru/index.php?id=1795.

17. Levitas A. Local Government Reform as State Building: What the Polish Case Says About «Decentralization».
Studies in comparative international development. 2017; 52(1):23-44, 2017. doi: 10.1007/s12116-015-9203-5.

18. Constitution of Ukraine (available online). 1996. https:// zakon.rada.gov.ua/laws/show/254

19. Bordenyuk $V$. Decentralization of State Power and Local Self-Government Concept of Essence and Form (Type). Pravo Ukrayiny. 2005;(1):21-5.

20. Alvarez $A B$. A new perspective for administrative optimization: regional reorganization in France. Revista General de Derecho Administrative. 2015;(39):9 p.

21. Boryslavs'ka $O$. Local Government in Ukraine: Theory and Practice in the Constitutional and Legal Framework: monograph. L. Pais. 2005:208.

22. Averianov Yu. Politics: Encyclopedic Dictionary. Mosk. Komerts. Un-tu. 1993:431.

23. Tkachuk A. Local Government and Decentralization. Zakonodavstvo navchal'nyy modul'. Kyiv. IKTS. Lehal'nyy status. 2017:80. ISBN 978-966-8312-84-7.

24. Hanushchak Yu. Reform of the Territorial Organization of Power. Swiss-Ukrainian project. Support for Decentralization in Ukraine. DESPRO. K.: LLC Sofia-A. 2013:160. ISBN 978-7031-14-6

25.Zakarpats'ka Region - Decentralization (available online). https://decentralization.gov.ua/areas/0312

26. Novakovsky L, Tretyak A, Dorosh Yu. Financial Sustainability of United Territorial Communities and Land Management: State Reform of the territorial organization of power and problems. Land Management, Cadaster and Land Monitoring. 2018;(4):4-13. doi.org/ 10.31548/ zemleustriy2018.04.01. 